\title{
Apresentação Editorial
}

A Cadernos de Relações Internacionais apresenta sua segunda edição de 2021 com temas que demonstram como o campo das Relações Internacionais tem expandido seu objeto de estudo e encontrando novas referências para a reflexão sobre a política internacional e os recentes desafios globais. Nesse sentido, os trabalhos aqui presentes são um reflexo de como temas na área têm sido tratados no âmbito da graduação a partir de abordagens alternativas. Embora em diferentes frentes, é importante reconhecer como os autores desta edição mobilizaram pesquisas desafiadoras com metodologias refinadas.

O trabalho do Daniel Bianco resgata a discussão sobre pirataria à luz do aumento desse fenômeno no Sudeste Asiático. O autor, por meio de uma literatura atualizada do tema, argumenta que o debate está passando por uma transição e que, por isso, é interessante que a pirataria, enquanto uma problemática de segurança internacional contemporânea, deve ser estudada dentro de um escopo mais global. Dessa maneira, é possível dar conta das múltiplas abordagens sobre o tema de maneira mais ampla, contribuindo para outras abordagens na literatura.

Voltando-se para o grande tema de política externa, Bianca Carvalho observa as relações entre o Mercosul e União Europeia no que tange à saúde pública brasileira. Por meio de entrevistas e análises legislativa e da literatura, a autora analisa o impacto do Acordo TRIPS na produção de medicamentos genéricos e seu lugar na discussão sobre propriedade intelectual. Bianca evidencia um tema que tem sido bastante discutido recentemente nos estudos de Saúde Global e avança na ponderação dos custos ao governo brasileiro caso sejam implementadas as sugestões do bloco europeu.

Já Luana Paris irá discorrer sobre os estudos estéticos e pós-coloniais para analisar a produção cinematográfica de Bollywood, cuja popularidade tem se expandido nos últimos anos. De acordo com a autora, é relevante observar essa indústria em paralelo com a projeção da Índia no cenário internacional e, sobretudo, a partir da (contra)-imagem do Norte Global em relação ao país. Assim, Paris sustenta uma argumentação crítica para compreender os limites dos estereótipos nacionais e como Bollywood os contesta enquanto também projeta uma narrativa dominante cultural dentro do próprio território indiano.

Destacamos também o artigo da Beatriz Carvalho sobre Tribunal Penal Internacional para a Antiga Iugoslávia, cujo trabalho foi reconhecido com o Prêmio Gerson Moura do IRI/PUC-Rio em 2021 - prêmio este dedicado aos melhores trabalhos de conclusão de curso da graduação. Beatriz se detém no processo de reconciliação entre os 
diferentes atores envolvidos nos conflitos de independência na Iugoslávia, observando como o Tribunal desempenhou um papel protagonista nessas relações. A autora também apresenta uma perspectiva crítica sobre o processo e seus limites que colocam em tensão as próprias bases do processo de construção da paz.

Por fim, a revista Cadernos de Relações Internacionais divulga este novo volume reconhecendo também o trabalho impecável de todos os pareceristas externos que contribuíram para que esta edição pudesse ser realizada. Acreditamos que a excelência de toda pesquisa conta muito com a generosidade e troca de colegas e mentores. Graças à leitura atenta dos convidados externos, pudemos reforçar nosso objetivo: que a Cadernos funcione como um lugar de incentivo para que autores, ainda finalizando seus cursos ou recém-formados, publiquem seus primeiros trabalhos da carreira e conheçam como funciona o processo editorial de uma revista científica.

Com isso, parabenizamos a todos e desejamos uma ótima leitura desta nova edição! 